\title{
Synthesis, Spectroscopic, Molecular Structure, and Antibacterial Studies of Dibutyltin(IV) Schiff Base Complexes Derived from Phenylalanine, Isoleucine, and Glycine
}

\author{
Har Lal Singh and Jangbhadur Singh \\ Department of Chemistry, Faculty of Engineering \& Technology, Mody University of Science and Technology, \\ Laxmangarh, Sikar, Rajasthan 332311, India
}

Correspondence should be addressed to Har Lal Singh; hlsingh9@rediffmail.com

Received 2 May 2014; Revised 13 July 2014; Accepted 16 July 2014; Published 27 November 2014

Academic Editor: Enrico Rizzarelli

Copyright (C) 2014 H. L. Singh and J. Singh. This is an open access article distributed under the Creative Commons Attribution License, which permits unrestricted use, distribution, and reproduction in any medium, provided the original work is properly cited.

\begin{abstract}
New series of organotin(IV) complexes and Schiff bases derived from amino acids have been designed and synthesized from condensation of $1 H$-indole-2,3-dione, 5-chloro- $1 H$-indole-2,3-dione, and $\alpha$-amino acids (phenylalanine, isoleucine, and glycine). All compounds are characterized by elemental analyses, molar conductance measurements, and molecular weight determinations. Bonding of these complexes is discussed in terms of their UV-visible, infrared, and nuclear magnetic resonance $\left({ }^{1} \mathrm{H}\right.$, ${ }^{13} \mathrm{C}$, and ${ }^{119}$ Sn NMR) spectral studies. The results suggest that Schiff bases behave as monobasic bidentate ligands and coordinate with dibutyltin(IV) in octahedral geometry according to the general formula $\left[\mathrm{Bu}_{2} \mathrm{Sn}(\mathrm{L})_{2}\right]$. Elemental analyses and NMR spectral data of the ligands with their dibutyltin(IV) complexes agree with their proposed distorted octahedral structures. Few representative compounds are tested for their in vitro antibacterial activity against Gram-positive (B. cereus, Staphylococcus spp.) and Gramnegative (E. coli, Klebsiella spp.) bacteria. The results show that the dibutyltin complexes are more reactive with respect to their corresponding Schiff base ligands.
\end{abstract}

\section{Introduction}

Amino acids and their compounds with different metal ions play an important role in pharmaceutical industries [1-5]. A number of studies have indicated that biologically active compounds become more bacteriostatic and carcinostatic upon chelation. Some drugs show increased activity when administered as metal chelates and inhibit the growth of tumor. Moreover, the development in the field of bioinorganic chemistry has increased the interest in Schiff base complexes, since it has been recognized that many of these may serve as models for biologically important species [6-9]. During the past few decades, research about new organotin compounds has increased dramatically, most likely due to their diverse biological applications [10-13]. A huge interest in metal complexes of Schiff bases derived from amino acids and salicylaldehyde has emerged due to their structural, magnetic, and electrochemical properties, as well as their potential use as models for a number of important biological systems [14-16]. Among their several biological functions, they show antimicrobial, antimalarial, antiproliferative, chemotherapeutic, radiopharmaceutical, insulin-mimetic, and fungicidal properties [17-23]. One of the most important bioinorganic chemistry research areas in organotin compounds is the investigation of their cytotoxic and antitumor activities [24]. Moreover, tin(IV) complexes characterized by the presence of one or more carbon-tin bonds have proved to be cytotoxic against the breast adenocarcinoma tumor and the colon carcinoma [25]. In general, the toxicity of organotin compounds seems to increase with the chain length of the organic alkyl groups, which are often more active than aryl ones [26, 27].

Although the major uses of these derivatives are well known for their versatile and significant important biological and pharmaceutical activities and as wood preservatives and pesticides [28-34], the organotin(IV) compounds possess potential applications in the field of industrial and 
medicinal chemistry. Organotin(IV) complexes have been extensively studied due to their coordination geometries as well as structural diversity. In view of this, the synthesis of organotin(IV) complexes of Schiff bases derived from the condensation of $1 \mathrm{H}$-indole-2,3-dione and 5-chloro- $1 \mathrm{H}$ indole-2,3-dione with different amino acids (phenylalanine, isoleucine, and glycine) derivatives is reported herein. The characterization of the complexes was realized by elemental analysis and spectroscopic (UV, IR, ${ }^{1} \mathrm{H},{ }^{13} \mathrm{C}$, and ${ }^{119} \mathrm{Sn}$ NMR) studies. Their antibacterial activities were screened against various Gram-positive and Gram-negative bacteria.

\section{Experimental}

All reagents were commercially available (Aldrich or Merck) and used as supplied. Solvents were purified and dried according to standard procedures and moisture was excluded from the glass apparatus using $\mathrm{CaCl}_{2}$ drying tubes. Melting points were determined in open glass capillaries and were uncorrected. The ligands were prepared by the condensation of isatin and 5-chloroisatin with amino acids (phenylalanine, isoleucine, and glycine) as described earlier [35].

2.1. Analytical Methods and Spectral Measurements. Tin was estimated gravimetrically as $\mathrm{SnO}_{2}$. CHN analyses were carried out on a Perkin Elmer 2400 Elemental Analyser. Molecular weight determinations were carried out by the Rast camphor method. Molar conductance measurements were made in anhydrous dimethylformamide at $25 \pm 5^{\circ} \mathrm{C}$ using a Systronics conductivity bridge model 305 . The electronic spectra were recorded in DMSO on a Thermo UV1 spectrophotometer. IR spectra were recorded on a Perkin Elmer Spectrum SP-2 Fourier transform spectrophotometer using $\mathrm{KBr}$ pellets $\left(4000-400 \mathrm{~cm}^{-1}\right) .{ }^{1} \mathrm{H}$ and ${ }^{13} \mathrm{C}$ NMR spectra were recorded on a Bruker Avance-II $(400 \mathrm{MHz})$ FTNMR spectrometer using DMSO- $\mathrm{d}_{6}$ as solvent at $400 \mathrm{MHz}$ and $100 \mathrm{MHz}$, respectively. TMS was used as internal reference for ${ }^{1} \mathrm{H}$ NMR and ${ }^{13} \mathrm{C}$ NMR. The ${ }^{119}$ Sn NMR spectra with proton noise decoupling were recorded on a Bruker AvanceII spectrometer using dry DMSO as the solvent at $149.21 \mathrm{MHz}$ and tetramethyltin (TMT) as an external standard. X-ray powder patterns were obtained with a SIEMENS D-5000 Xray diffractometer using $\mathrm{Cu} \mathrm{K \alpha}$ radiation $(l=1.5405984 \AA)$ which was operated at $30 \mathrm{kV}$ and $15 \mathrm{~mA}$.

2.2. 3D Molecular Modeling Analysis. The molecular modeling of a representative compound was carried out on a CS Chem3D Ultra Molecular Modeling and using MM2 analysis program [36]. It is an interactive graphics program that allows rapid structure building, geometry optimization with minimum energy, and molecular display. Correct sequence of atoms was obtained to get reasonable low energy molecular models to determine their molecular representation in three dimensions. Complications of molecular transformations could be explored using output obtained. An attempt to gain a better insight into the molecular structure of compounds, geometric optimization, and conformational analysis was performed using MM2 force field [37].
2.3. Syntheses of Organotin(IV) Complexes. Dibutyltin(IV) oxide $(0.280 \mathrm{~g} ; 1.125 \mathrm{mmol})$ was added to the calculated amount of the ligands $(0.491-0.829 \mathrm{~g} ; 2.250 \mathrm{mmol})$ in a $1: 2$ molar ratio in dry benzene $(75 \mathrm{~mL})$, with methanol $(25 \mathrm{~mL})$ mixture as reaction medium. The contents were refluxed on a fractionating column for about 5-7 hours. The water liberated in the reaction was removed azeotropically with benzene. On completion of the reaction, the resulting products were rendered free from solvent and then washed repeatedly with dry cyclohexane. The crystalline solids were separated out and purified by recrystallization from the same solvent. The products so formed were finally dried in vacuum at $40 \pm$ $5^{\circ} \mathrm{C}$ for 2-3 hours. The purity of the complexes was checked by TLC using silica gel type $G$ as adsorbent. Their physical properties and analytical data were recorded in Table 1.

2.4. Antibacterial Activity. Synthesized compounds were screened for their antibacterial activity against Gram-positive (B. cereus, Staphylococcus spp.) and Gram-negative (E. coli, Klebsiella spp.) bacteria at two concentrations $500 \mathrm{ppm}$ and $200 \mathrm{ppm}$. The compounds were dissolved in DMSO. The in vitro antibacterial activity of the free ligands and their tin complexes was tested using the agar well diffusion method [38]. Using a sterile cork borer (5 $\mathrm{mm}$ in diameter) wells were made in each agar plate, more than $0.1 \mathrm{~mL}$ of the tested compounds were poured into three wells, and the dishes were incubated at $28 \pm 2^{\circ} \mathrm{C}$ for 24 hours. The growth of the microorganisms was inhibited by diffusion of the test solutions and then the inhibition zone around the well was measured. The antibacterial activity of each compound was compared with standard antibiotics such as streptomycin. DMSO was used as a control under the same conditions to test organisms and no activity was found.

\section{Results and Discussion}

New organotin(IV) complexes were synthesized by the reactions of dibutyltin(IV) oxide with Schiff bases, which have been carried out in $1: 2$ molar ratios using anhydrous benzene and absolute methanol in a 3:1 ratio as solvent. These reactions proceed with the liberation of water, which was azeotropically removed. The results of elemental analysis (C, $\mathrm{H}$, and $\mathrm{N}$ ) with molecular formula and the melting points are presented in Table 1. The results obtained are in good agreement with those calculated for the suggested formula. The scheme of the organotin(IV) complexes preparation is given below (Scheme 1).

The above reactions were found to be quite facile and could be completed in 5-7 h of refluxing. All these complexes are intensively coloured and are solids. They are soluble in methanol, DMF, and DMSO. The compounds were dissolved in DMF and molar conductance $10^{-3} \mathrm{M}$ of solution at $25^{\circ} \mathrm{C}$ was measured. The molar conductance values of the complexes fall in the range from 10.32 to $20.14 \Omega^{-1} \mathrm{~cm}^{2} \mathrm{~mol}^{-1}$ indicating that these compounds are nonelectrolytes.

3.1. Electronic Spectra. The spectra of the ligands and their complexes were recorded in dry DMSO. The various bands 


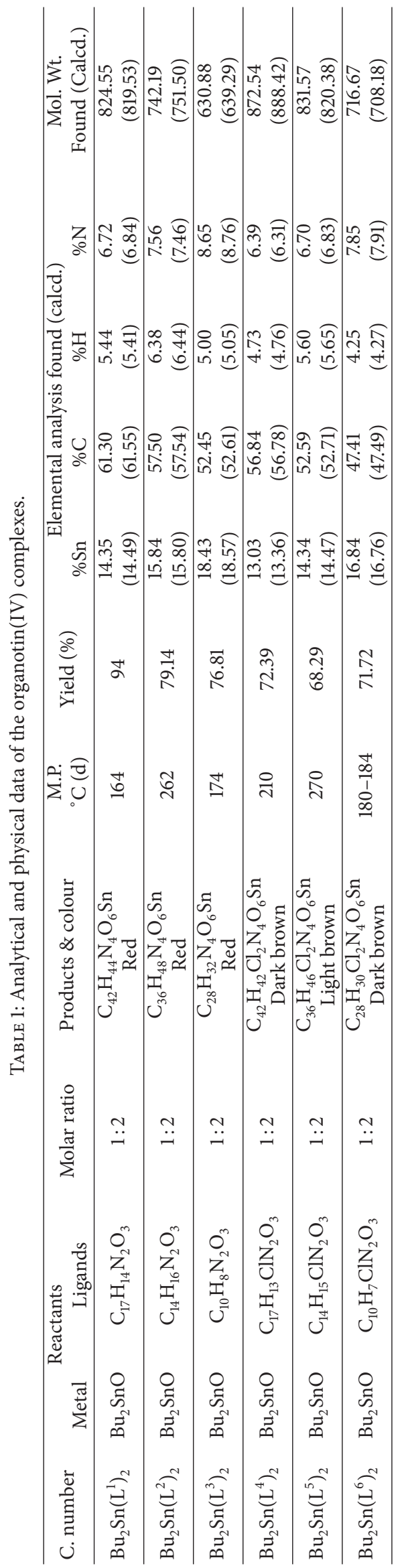




$$
\begin{aligned}
& \mathrm{Bu}_{2} \mathrm{SnO}+2 \mathrm{~N} \mathrm{OH} \frac{\text { Methanol }+ \text { benzene }}{\text { Reflux } 5-7 \mathrm{~h}} \mathrm{Bu}_{2} \mathrm{Sn}(\mathrm{NO})_{2}+\mathrm{H}_{2} \mathrm{O} \\
& \text { where } \mathrm{N} \text { OH represents the donor system of the Schiff bases }
\end{aligned}
$$

SCHEME 1: Representative equation illustrating the formation of dibutyltin(IV) complexes.

observed were assigned to interligand and charge transfer of $n-\pi^{*}$ transitions according to their energies and intensities. Two intense maxima are observed in the complexes at 210-232 and 375-382 $\mathrm{nm}$ ranges which may be assigned to $n-\pi^{*}$ transition of the carboxylate [39] and of the $\mathrm{C}=\mathrm{N}$ chromophore. The appreciable shifting observed in the $n-\pi^{*}$ transition $(\sim 370 \mathrm{~nm})$ is due to the polarization in the $\mathrm{C}=\mathrm{N}$ bond caused by tin-ligand electron interaction. This clearly indicates the coordination of the azomethine nitrogen with the tin atom. A band in the region $355-338 \mathrm{~nm}$ in the spectra of the Schiff bases and complexes is likely to be the secondary band of the benzene ring coupled with the intramolecular charge transfer transition taking place within the ligand moiety. Furthermore, sharp bands were observed in the region $246-332 \mathrm{~nm}$ in the spectra of the complexes which could be assigned to the charge transfer transition from ligand to tin atom [40].

3.2. Infrared Spectra. The IR spectra of these compounds have been recorded in the range of $4000-400 \mathrm{~cm}^{-1}$. Tentative assignments have been made on the basis of earlier publications and the important data are listed in Table 2. The absorptions of interest in the spectra of the complexes are $\nu(\mathrm{COO}), \nu(\mathrm{Sn}-\mathrm{C})$, and $\nu(\mathrm{Sn}-\mathrm{O})$. The position and the intensities of these peaks are expected to be changed on chelation. New peaks and quasi-peaks are also a guide to chelation. The IR spectra of all the ligands show the absence of bands at 3450 and $1750 \mathrm{~cm}^{-1}$ due to $\nu\left(\mathrm{NH}_{2}\right)$ group of amino acids and $v(\mathrm{C}=\mathrm{O})$ of isatin. Instead, a new prominent band at $1635 \pm 5 \mathrm{~cm}^{-1}$ due to azomethine $\nu(\mathrm{C}=\mathrm{N})$ linkage appeared in all the ligands $[12,34]$, indicating that condensation between ketone moiety of isatin and that of amino group of amino acids has taken place resulting in the formation of the desired ligands $\left(\mathrm{L}^{1} \mathrm{H}-\mathrm{L}^{6} \mathrm{H}\right)$. Moreover, comparison of the IR spectra of the ligands with their organotin(IV) complexes showed a major shift to lower wave numbers by $10-15 \mathrm{~cm}^{-1}$ in azomethine $v(\mathrm{C}=\mathrm{N})$ at $1620 \pm 5 \mathrm{~cm}^{-1}$ suggesting the involvement of the azomethine nitrogen with the organotin(IV) ion $[9,11$, 32]. The appearance of a new band of medium intensity in the region $\sim 552-540 \mathrm{~cm}^{-1}$ in all of the derivatives studied, which may be assigned to $\nu(\mathrm{Sn} \leftarrow \mathrm{N})$, further confirms the coordination of the amino nitrogen with the tin moiety.

The absence of the $v(\mathrm{COOH})$ in all the organotin(IV) compounds in the $2750-3100 \mathrm{~cm}^{-1}$ region and the presence of $\nu(\mathrm{Sn}-\mathrm{O})$ in the $432-420 \mathrm{~cm}^{-1}$ range indicate deprotonation of the carboxylic acid group and consequent coordination of the carboxylate group with the tin metal as expected. IR stretching frequencies $v_{\text {as }}(\mathrm{OCO})$ and $v_{\mathrm{s}}(\mathrm{OCO})$ for carboxylates have been utilized as a characteristic tool to confirm the mode of coordination through carboxylate oxygen and also to identify the nature (monodentate, bidentate, or bridging/chelating) of bonding of the carboxylate group. Unless the carboxylate group is branched at the $\alpha$-carbon or the organic substituents at the tin atom are bulky, carboxylate groups in organotin(IV) carboxylates generally adopt a bridge structure in the solid state [41]. The IR stretching frequencies of the carboxylate groups are very important for determining their structures; namely, when there are interactions between the carbonyl oxygen atoms of the carboxylate groups and the tin atom, the asymmetric absorption vibration frequencies $v_{\text {as }}(\mathrm{OCO})$ of the carboxylate groups decrease and the symmetric absorption frequencies $v_{s}(\mathrm{OCO})$ increase. In the IR spectra of the title compounds, the carboxylate bands are observed in the characteristic regions for $v_{\text {as }}(\mathrm{OCO})$ between 1610 and $1590 \mathrm{~cm}^{-1}$ and for $v_{s}$ (OCO) between 1340 and $1325 \mathrm{~cm}^{-1}$ (Table 2). In the diorganotin(IV) complexes, the differences $[v \Delta(\mathrm{OCO})]$ between $v_{\mathrm{as}}(\mathrm{OCO})$ and $v_{\mathrm{s}}(\mathrm{OCO})$ are more than $200 \mathrm{~cm}^{-1}$ indicating the covalent nature of the metal-oxygen bond. Ionic bonding and also bridging or chelation, therefore, can be excluded, and unidentate coordination of the carboxylic groups bonding to the metal must therefore be assumed. Thus, for diorganotin compounds the $v \Delta(\mathrm{OCO})$ values were found to be more than $200 \mathrm{~cm}^{-1}$, which indicates that the carboxylate groups are chelated and bonded to the metal in a unidentate manner. Moreover, for complexes $\Delta v$ below $200 \mathrm{~cm}^{-1}$ would be expected for bridging or chelating carboxylate, but greater than $200 \mathrm{~cm}^{-1}$ for the monodentate bonding carboxylate anions. Further evidence for the coordination with tin via oxygen atom was revealed by the presence of the $\nu(\mathrm{Sn}-\mathrm{O})$ [33] stretching bands in the spectra of complexes in the region of $432-420 \mathrm{~cm}^{-1}$. Besides this, several new bands in the complexes observed at $\sim 630 \mathrm{~cm}^{-1}$, $\sim 540 \mathrm{~cm}^{-1}$, and $\sim 430 \mathrm{~cm}^{-1}$ may be $\nu(\mathrm{Sn}-\mathrm{C})[34], \nu(\mathrm{Sn} \leftarrow \mathrm{N})$ [12], and $\nu(\mathrm{Sn}-\mathrm{O})$ [38], respectively. The vacant $5 \mathrm{~d}$ orbital of tin atoms tends toward high coordination with ligands containing lone pairs of electrons. The intensity observed for the symmetric $\mathrm{Sn}-\mathrm{CH}_{2}$ stretching vibration at $\sim 1440 \mathrm{~cm}^{-1}$ indicates a bent $\mathrm{C}-\mathrm{Sn}-\mathrm{C}$ moiety for the dibutyltin complexes. These data are consistent with a distorted octahedral configuration for the tin atom.

3.3. ${ }^{1} \mathrm{H}$ NMR Spectra. The chemical shifts ( $\delta \mathrm{ppm}$ ) of various protons in the complexes in DMSO- $\mathrm{d}_{6}$ solution are given in Table 3. The conclusions drawn from ${ }^{1} \mathrm{H}$ NMR spectral studies lend further support to the mode of bonding discussed above. The absence of a signal at $\delta 12.00-11.00 \mathrm{ppm}$ due to the $\mathrm{C}(\mathrm{O}) \mathrm{OH}$ proton suggests the deprotonation of the carboxylic oxygen atom of the ligands on complexation. The ligands give a complex multiplet signal in the region $\delta 7.10-7.85 \mathrm{ppm}$ for the aromatic protons and these remain almost at the same position in the spectra of the metal complexes. The appearance of signals due to $\mathrm{NH}$ protons at the same positions in the ligand and its complexes shows the noninvolvement of this group in coordination. The butyl protons attached to tin appear as multiplets due to $-\mathrm{CH}_{2}-\mathrm{CH}_{2}-\mathrm{CH}_{2}$ - protons in the $\delta 1.65-1.15 \mathrm{ppm}$ region and as a clear triplet or broad signal due to terminal methyl protons in the $\delta 0.80-0.85 \mathrm{ppm}$ region 
TABLE 2: Important IR spectral data $\left(\mathrm{cm}^{-1}\right)$ of Schiff bases and their corresponding organotin(IV) complexes.

\begin{tabular}{|c|c|c|c|c|c|c|c|c|c|}
\hline Compounds & $v(\mathrm{OH}) v$ & $\nu(\mathrm{C}=\mathrm{N}-)$ & $\nu(\mathrm{C}=\mathrm{O})$ & $v_{\mathrm{as}}(\mathrm{COO})$ & $v_{s}(\mathrm{COO})$ & $\Delta v$ & $\nu(\mathrm{Sn} \leftarrow \mathrm{N})$ & $v(\mathrm{Sn}-\mathrm{O})$ & $\nu(\mathrm{Sn}-\mathrm{C})$ \\
\hline $\mathrm{L}^{1} \mathrm{H}$ & $3090-2740 \mathrm{br}$ & $1620 \mathrm{~s}$ & $1728 \mathrm{~s}$ & - & - & - & - & - & - \\
\hline $\mathrm{Bu}_{2} \mathrm{Sn}\left(\mathrm{L}^{1}\right)_{2}$ & - & $1610 \mathrm{~s}$ & $1722 \mathrm{~s}$ & 1590 vs & $1325 \mathrm{~s}$ & 265 & $540 \mathrm{w}$ & $430 \mathrm{~m}$ & $622 \mathrm{~m}$ \\
\hline $\mathrm{L}^{2} \mathrm{H}$ & $3100-2740$ br & $1625 \mathrm{~s}$ & $1730 \mathrm{~s}$ & - & - & - & - & - & - \\
\hline $\mathrm{Bu}_{2} \mathrm{Sn}\left(\mathrm{L}^{2}\right)_{2}$ & - & $1612 \mathrm{~s}$ & $1726 \mathrm{~s}$ & $1605 \mathrm{~m}$ & $1333 \mathrm{~m}$ & 272 & $545 \mathrm{~m}$ & $426 \mathrm{~s}$ & $640 \mathrm{~m}$ \\
\hline $\mathrm{L}^{3} \mathrm{H}$ & $3090-2750$ br & $1630 \mathrm{~s}$ & $1720 \mathrm{~s}$ & - & - & - & - & - & - \\
\hline $\mathrm{Bu}_{2} \mathrm{Sn}\left(\mathrm{L}^{3}\right)_{2}$ & - & $1616 s$ & $1722 \mathrm{~s}$ & $1601 \mathrm{~s}$ & $1332 \mathrm{~m}$ & 268 & $552 \mathrm{~m}$ & $425 \mathrm{~m}$ & $630 \mathrm{~m}$ \\
\hline $\mathrm{L}^{4} \mathrm{H}$ & $3110-2750$ br & $1622 \mathrm{~s}$ & $1735 \mathrm{~s}$ & - & - & - & - & - & - \\
\hline $\mathrm{Bu}_{2} \mathrm{Sn}\left(\mathrm{L}^{4}\right)_{2}$ & - & $1605 \mathrm{~s}$ & $1732 \mathrm{~s}$ & $1608 \mathrm{~s}$ & $1330 \mathrm{~m}$ & 278 & $545 \mathrm{~s}$ & $420 \mathrm{w}$ & $635 \mathrm{~m}$ \\
\hline $\mathrm{L}^{5} \mathrm{H}$ & $3080-2730 \mathrm{br}$ & $1630 \mathrm{~s}$ & $1735 \mathrm{~s}$ & - & - & - & - & - & - \\
\hline $\mathrm{Bu}_{2} \mathrm{Sn}\left(\mathrm{L}^{5}\right)_{2}$ & - & $1612 \mathrm{~s}$ & $1734 \mathrm{~s}$ & 1595 vs & $1326 \mathrm{~s}$ & 269 & $540 \mathrm{w}$ & $425 \mathrm{w}$ & $625 \mathrm{~m}$ \\
\hline $\mathrm{L}^{6} \mathrm{H}$ & $3109-2730$ br & $1622 \mathrm{~s}$ & $1725 \mathrm{~s}$ & - & - & - & - & - & - \\
\hline $\mathrm{Bu}_{2} \mathrm{Sn}\left(\mathrm{L}^{6}\right)_{2}$ & - & $1610 \mathrm{~s}$ & $1728 \mathrm{~s}$ & 1610 vs & $1340 \mathrm{vs}$ & 270 & $544 \mathrm{w}$ & $432 \mathrm{~m}$ & $632 \mathrm{~m}$ \\
\hline
\end{tabular}

br: broad, vs: very sharp, v: sharp, m: medium, and w: weak.

with ${ }^{3} J_{H H}=7.35 \mathrm{~Hz}$. The $>\mathrm{CH}-$ protons in the complexes of the ligands give signals in the $\delta 4.38-3.99$ ppm region. The most important piece of information, obtained from ${ }^{1} \mathrm{H}$ NMR values in these compounds, demonstrates that diorganotin(IV) complexes show the coordination number greater than four, probably six, in noncoordinating solvent. The number of protons of various groups calculated from the integration curves and the number of those calculated for the expected molecular formula agree with each other.

3.4. ${ }^{13}$ C NMR Spectra. The ${ }^{13} \mathrm{C}$ NMR spectral data along with assignment of characteristic peaks of ligands and its diorganotin(IV) complexes are presented in Table 4. The signals due to the carbon atoms attached to the carboxylate oxygen and the azomethine groups in the ligands appear at $\sim \delta 176 \mathrm{ppm}$ and $\sim \delta 163$ ppm, respectively. However, in the spectra of the corresponding tin complexes, these appear at $\sim \delta 185 \mathrm{ppm}$ (carboxylate group) and at $\sim \delta 155 \mathrm{ppm}$ (azomethine group), respectively. The considerable shifts in the resonances of the carbon atoms attached to oxygen and nitrogen indicate the involvement of oxygen and nitrogen atoms in coordination. The alkyl carbons of Schiff base and organotin(IV) complexes appear well within the expected ranges and their assignments are given in Table 4 . The heteronuclear coupling constant ${ }^{1} J\left({ }^{13} \mathrm{C}-{ }^{119} \mathrm{Sn}\right)$ in the studied organotin(IV) complexes is determined, which provides vital information about the coordination environment and the geometry of the complexes. In all the complexes, the alkyl group are observed with coupling constant of the values ${ }^{1} J\left({ }^{13} \mathrm{C}-{ }^{119} \mathrm{Sn}\right)$ are in the range $690.56-759.86 \mathrm{~Hz}$. These values lie in a typical range for six-coordinated organotin(IV) complexes [42].

3.5. ${ }^{119}$ Sn NMR Spectra. The ${ }^{119}$ Sn NMR chemical shifts are very sensitive to coordination number of tin and are generally shifted upfield on bonding to Lewis base. It has been reported $[43,44]$ that the ${ }^{119} \mathrm{Sn}$ chemical shifts in the ranges from 200 to -60 , from -90 to -190 , and from -210 to -400 ppm are associated with four-, five-, and sixcoordinated alkyltin(IV) compounds, and these ${ }^{119} \mathrm{Sn}$ shifts are higher with aryltin(IV) compounds. In the ${ }^{119} \mathrm{Sn}$ NMR spectra of $\mathrm{Bu}_{2} \mathrm{Sn}\left(\mathrm{L}^{1}\right)_{2}, \mathrm{Bu}_{2} \mathrm{Sn}\left(\mathrm{L}^{2}\right)_{2}$, and $\mathrm{Bu}_{2} \mathrm{Sn}\left(\mathrm{L}^{3}\right)_{2}$ recorded in DMSO- $\mathrm{d}_{6}$, the ${ }^{119} \mathrm{Sn}$ chemical shifts are observed at $\delta-265.4,-270.8$, and $-266.1 \mathrm{ppm}$, respectively, lying in the range of six-coordinated tin. The ${ }^{1} J\left({ }^{119} \mathrm{Sn}-{ }^{13} \mathrm{C}\right)$ values allow the calculation of the bond angle for the $\mathrm{C}-\mathrm{Sn}-\mathrm{C}$ fragment, which is in the order of $\sim 117^{\circ}$, suggesting that the tin atom has a slightly distorted octahedral geometry (Figure 1); this behavior is in agreement with the values reported for hexacoordinated tin compounds [45].

3.6. X-Ray Powder Diffraction Studies. The X-ray diffraction studies have been performed on Philips PW 1710 automated $\mathrm{X}$-ray powdered diffractometer. The experimental conditions employed in reading the pattern were as follows: the operating target voltage was $30 \mathrm{kV}$; the tube current was $15 \mathrm{~mA}$. The X-ray from copper target was filtered with nickel, and monochromatic K $\alpha$ line of wavelength $1.540598 \AA$ was obtained. Filtration reduces noise due to white radiation and increases resolution also.

The X-ray diffraction of $\mathrm{L}^{1} \mathrm{H}, \mathrm{L}^{2} \mathrm{H}, \mathrm{L}^{3} \mathrm{H}$, and their metal complexes indicates the crystalline nature of the $\mathrm{L}^{1} \mathrm{H}, \mathrm{L}^{2} \mathrm{H}$, and $\mathrm{L}^{3} \mathrm{H} ; \mathrm{Bu}_{2} \mathrm{Sn}\left(\mathrm{L}^{3}\right)_{2}$ is shown to have amorphous nature. All the reflection has been indexed for $D$ (particle size) using Scherrer's equation. Average crystallite size values of $22.484 \mathrm{~nm}$ and $32.439 \mathrm{~nm}$ were shown for $\mathrm{L}^{1} \mathrm{H}$ and $\mathrm{L}^{2} \mathrm{H}$, respectively. These values of particle size and $2 \theta$ for each peak have been calculated with the help of the cell parameters and corresponding FWHM values. The lattice spacing, FWHM, and particle size for $\mathrm{L}^{1} \mathrm{H}$ and $\mathrm{L}^{2} \mathrm{H}$ have been found out and are given in Table 5. The diffractogram of compounds has been shown in Figures 2 and 3.

3.7. Molecular Structure. Molecular modeling helped to demonstrate the significant features, that is, molecular geometries, bond energy, and torsion angles of organometallic frameworks theoretically. Bond lengths, bond angles, and atomic coordinates depend on the hybridization of an atom and mode of bonding. Thus, molecular modeling was the blue 


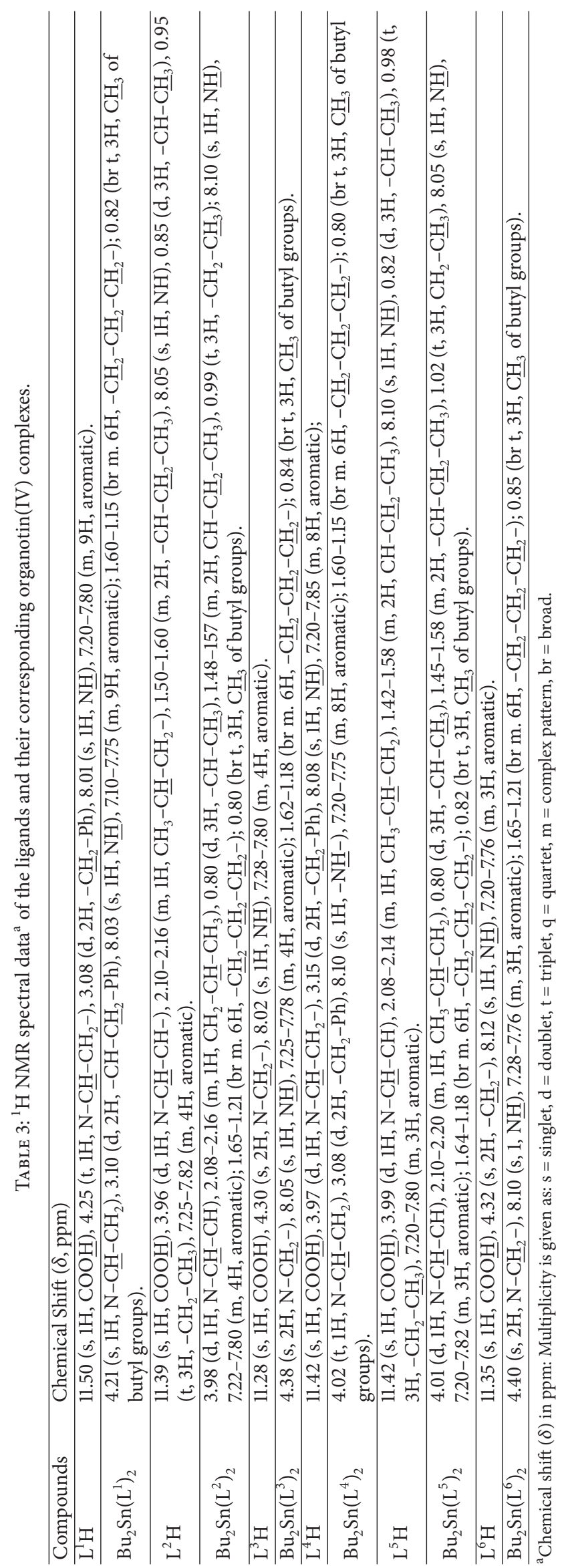


TABLE $4:{ }^{13} \mathrm{C}$ NMR spectral data of the ligands and their corresponding organotin(IV) complexes.

\begin{tabular}{|c|c|c|c|c|c|c|}
\hline \multirow{2}{*}{ Compounds } & \multicolumn{6}{|c|}{ Chemical shift in $(\delta \mathrm{ppm})$} \\
\hline & $\mathrm{COOH}$ & $\mathrm{CH}$ & $\mathrm{C}=\mathrm{N}$ & $\mathrm{CH}_{2} / \mathrm{CH}_{3}$ & Aromatic carbons & $\mathrm{Sn}-{ }^{\alpha} \mathrm{CH}_{2}-{ }^{\beta} \mathrm{CH}_{2}-{ }^{\gamma} \mathrm{CH}_{2}-{ }^{\delta} \mathrm{CH}_{3}$ \\
\hline $\mathrm{L}^{1} \mathrm{H}$ & 176.8 & 67.8 & 163.4 & 38.2 & $\begin{array}{c}149.2,135.8,133.0,128.6,127.5,126.3 \\
124.6,122.9,120.1\end{array}$ & - \\
\hline $\mathrm{Bu}_{2} \mathrm{Sn}\left(\mathrm{L}^{1}\right)_{2}$ & 185.4 & 65.7 & 155.2 & 39.4 & $\begin{array}{c}150.0,136.1,132.6,128.2,127.1,126.5 \\
124.4,123.3,120.2\end{array}$ & $\mathrm{C}-\alpha, 22.2 ; \mathrm{C}-\beta, 25.6 ; \mathrm{C}-\gamma, 22.4 ; \mathrm{C}-\delta, 13.4$ \\
\hline $\mathrm{L}^{2} \mathrm{H}$ & 178.5 & 65.7 & 162.4 & $16.3,21.3$ & $145.8,133.2,130.5,126.2,124.0,119.3$ & - \\
\hline $\mathrm{Bu}_{2} \mathrm{Sn}\left(\mathrm{L}^{2}\right)_{2}$ & 184.9 & 66.2 & 154.6 & $17.4,22.1$ & $146.2,132.9,130.8,126.54,124.3,120.1$ & C- $\alpha, 21.4 ;$ C- $\beta, 25.3 ;$ C- $\gamma, 21.6 ;$ C- $\delta, 13.5$ \\
\hline $\mathrm{L}^{3} \mathrm{H}$ & 176.1 & - & 163.6 & 52.4 & $148.5,131.0,129.8,125.3,122.9,119.1$ & - \\
\hline $\mathrm{Bu}_{2} \mathrm{Sn}\left(\mathrm{L}^{3}\right)_{2}$ & 183.7 & - & 154.5 & 58.3 & $149.0,132.5,129.6,125.7,123.4,119.6$ & $\mathrm{C}-\alpha, 22.1 ; \mathrm{C}-\beta, 25.2 ; \mathrm{C}-\gamma, 22.3 ; \mathrm{C}-\delta, 14.1$ \\
\hline $\mathrm{L}^{4} \mathrm{H}$ & 178.5 & 65.7 & 162.4 & 39.1 & $\begin{array}{c}150.2,136.1,132.8,129.5,127.3,126.4 \\
123.2,122.4,119.8\end{array}$ & - \\
\hline $\mathrm{Bu}_{2} \mathrm{Sn}\left(\mathrm{L}^{4}\right)_{2}$ & 184.5 & 66.2 & 154.5 & 38.7 & $\begin{array}{c}149.5,135.7,132.1,130.4,126.9,126.2 \\
123.5,122.1,120.3\end{array}$ & C- $\alpha, 22.4 ; C-\beta, 26.7 ;$ C- $\gamma, 22.8 ;$ C- $\delta, 14.6$ \\
\hline $\mathrm{L}^{5} \mathrm{H}$ & 177.5 & 66.2 & 163.1 & $17.3,20.5$ & $147.7,132.8,131.3,126.6,123.8,120.3$ & - \\
\hline $\mathrm{Bu}_{2} \mathrm{Sn}\left(\mathrm{L}^{5}\right)_{2}$ & 184.1 & 67.4 & 153.8 & $18.0,20.2$ & $148.1,132.4,129.7,126.5,124.0,120.2$ & C- $\alpha, 22.0 ;$ C- $\beta, 26.1 ;$ C- $\gamma, 22.5 ;$ C- $\delta, 13.4$ \\
\hline $\mathrm{L}^{6} \mathrm{H}$ & 176.9 & - & 162.9 & 55.4 & $149.5,132.8,128.9,125.7,123.0,120.3$ & - \\
\hline $\mathrm{Bu}_{2} \mathrm{Sn}\left(\mathrm{L}^{6}\right)_{2}$ & 182.8 & - & 155.4 & 56.1 & $148.2,133.1,128.5,125.8,122.7,120.5$ & C- $\alpha, 21.2 ;$ C- $\beta, 25.3 ;$ C- $\gamma, 22.24 ;$ C- $\delta, 13.7$ \\
\hline
\end{tabular}
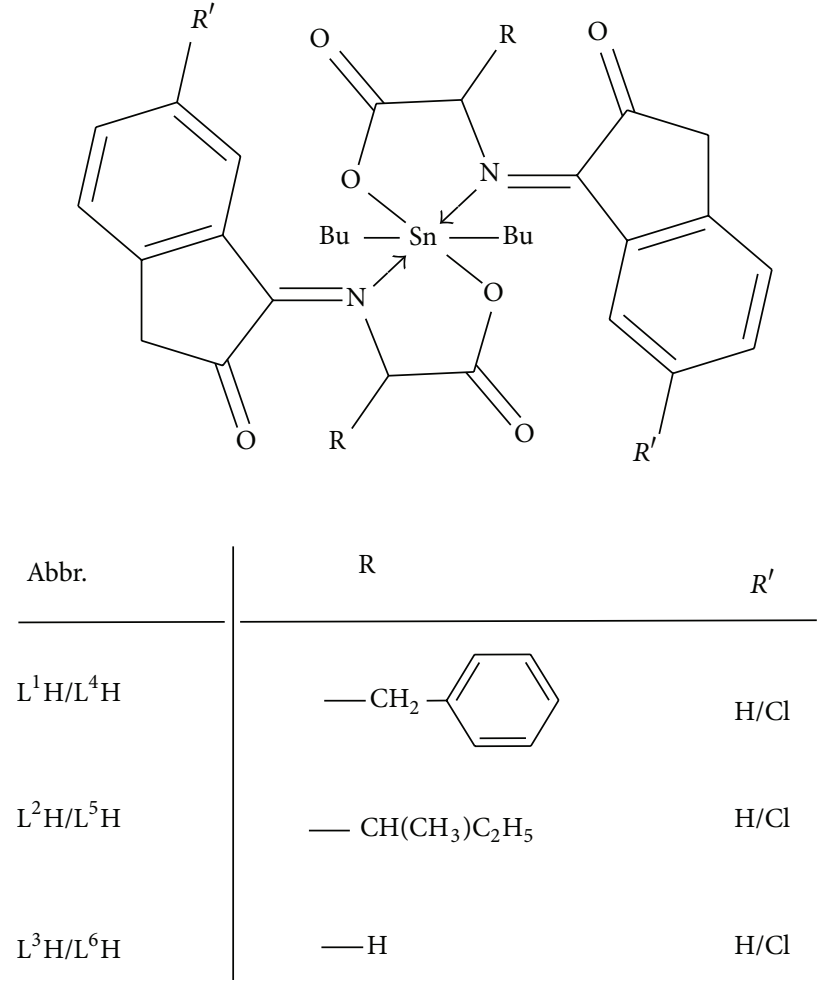

FIGURE 1: Structure of diorganotin(IV) complexes.

print of three dimensional arrangements of atoms. Beside this, if deviations in bond distance, bond angles, or torsion angles are evidenced, specific electronic interactions can be detected and confirmed to the earlier spectral lines of evidence [46]. The bonding capabilities of atoms have impact on bond lengths and bond angles of concerned

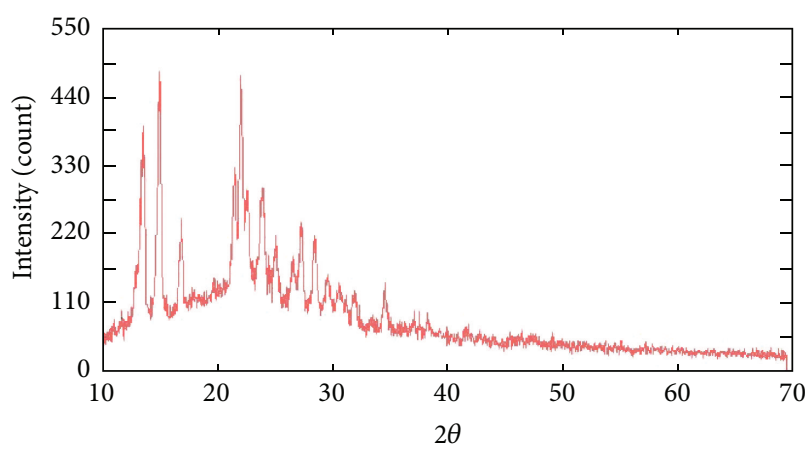

FIGURE 2: X-ray powder diffraction patterns of the compound $\left[\mathrm{L}^{1} \mathrm{H}\right]$.

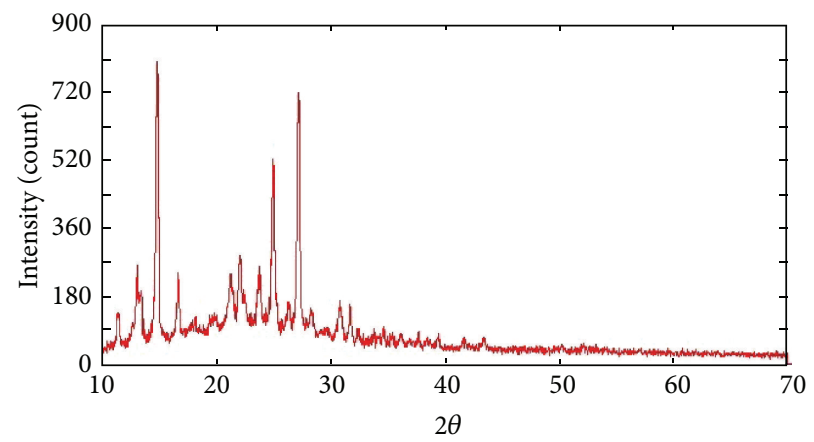

Figure 3: X-ray powder diffraction patterns of the compound $\left[\mathrm{L}^{2} \mathrm{H}\right]$.

functional groups. Therefore, molecular models of complexes were demonstrated. Physical dimension of the molecules helped out to demonstrate the changes occurring during their topological assemblies. Energy minimization is used to find 
TABLE 5: X-ray powder diffraction data for compounds $\left(L^{1} \mathrm{H}\right)$ and $\left(\mathrm{L}^{2} \mathrm{H}\right)$.

\begin{tabular}{lccccc}
\hline S. number & $2 \theta$ & “d” $(\AA)$ & Intensity (count) & FWHM & $D^{*}(\mathrm{~nm})$ \\
\hline & & \multicolumn{5}{c}{$\mathrm{L}^{1} \mathrm{H}$} \\
1 & 13.517 & 6.54547 & 385.6 & 0.5425 & 25.381 \\
2 & 14.936 & 5.92655 & 482.3 & 0.4308 & 31.912 \\
3 & 16.873 & 5.25031 & 216.5 & 0.7307 & 18.770 \\
4 & 21.492 & 4.13128 & 323.9 & 0.7307 & 18.643 \\
5 & 22.046 & 4.02874 & 453.9 & 0.6139 & 22.169 \\
6 & 22.521 & 3.94474 & 289.4 & 0.6139 & 22.151 \\
7 & 24.025 & 3.70113 & 301.8 & 0.6139 & 22.091 \\
8 & 24.805 & 3.58649 & 162.8 & 0.6139 & 22.059 \\
9 & 25.067 & 3.54964 & 205.2 & 0.6139 & 22.047 \\
10 & 26.359 & 3.37851 & 150.7 & 0.6139 & 21.991 \\
11 & 27.324 & 3.26131 & 228.2 & 0.486 & 27.722 \\
12 & 28.440 & 3.13581 & 217.5 & 0.7166 & 18.756 \\
13 & 32.024 & 2.79258 & 112.5 & 0.7166 & 18.598 \\
\hline & & & $L^{2} \mathrm{H}$ & & \\
1 & 11.495 & 7.69156 & 128 & 0.3461 & 39.860 \\
2 & 13.137 & 6.73368 & 236.3 & 0.3806 & 36.191 \\
3 & 14.870 & 5.95279 & 807.9 & 0.2844 & 48.343 \\
4 & 16.683 & 5.30969 & 228.6 & 0.3597 & 38.139 \\
5 & 21.263 & 4.17518 & 222.4 & 0.3597 & 37.885 \\
6 & 22.035 & 4.03068 & 286.1 & 0.5986 & 22.736 \\
7 & 23.706 & 3.75021 & 263.9 & 0.5544 & 24.476 \\
9 & 24.902 & 3.57273 & 521.9 & 0.3499 & 38.695 \\
10 & 26.232 & 3.39454 & 156.1 & 0.3499 & 38.593 \\
11 & 27.114 & 3.28608 & 717.3 & 0.2874 & 46.899 \\
\hline & 31.637 & 2.82587 & 144.2 & 0.4665 & 28.597 \\
& 37.570 & 2.3921 & 84.3 & 0.6166 & 21.289 \\
\hline & & & &
\end{tabular}

${ }^{*} D$ : crystallite size (in $\AA$ ) and $d$ : lattice spacing.

the structure with lowest energy using molecular mechanics analysis program $[47,48]$; data analysis of bond lengths and bond angles is presented in Tables 6 and 7 .

The molecular structure is shown in Figure 4. The deprotonated ligand is coordinated as bidentate ligand via the carboxylate oxygen and azomethine nitrogen atoms. The six coordination number is completed by two carbon atoms of butyl groups. The organic molecule acts as an anionic bidentate with the ON donors placed in the same side. Since the synthesized compounds are related and differ only in substituted $\mathrm{R}$ group, one compound $\mathrm{Bu}_{2} \mathrm{Sn}\left(\mathrm{L}^{2}\right)_{2}$ was theoretically studied. Based upon spectroscopic data, $\mathrm{Sn}$ (IV) compounds with $\mathrm{O}_{2} \mathrm{~N}_{2}$ ligands generally adopt distorted octahedral geometry. The optimized structure for the compound $\mathrm{Bu}_{2} \mathrm{Sn}\left(\mathrm{L}^{2}\right)_{2}$ is shown in Figure 4 and pertinent bond parameters are given in Tables 6 and 7. The bond angles around tin atom, for example, $\mathrm{C}(47)-\mathrm{Sn}(1)-\mathrm{C}(44)$ angle of $117.15^{\circ}, \mathrm{N}(5)-\mathrm{Sn}(1)-\mathrm{N}(9)$ angle of $148.95^{\circ}$, and $\mathrm{O}(6)-\mathrm{Sn}(1)-$ $\mathrm{O}(2)$ angle of $112.00^{\circ}$, in $\mathrm{Bu}_{2} \mathrm{Sn}\left(\mathrm{L}^{2}\right)_{2}$ are the representative
TABLE 6: Important bond lengths of compound $\left[\mathrm{Bu}_{2} \mathrm{Sn}\left(\mathrm{L}^{2}\right)_{2}\right]$.

\begin{tabular}{lccc}
\hline S. number & Atoms & Actual $(\AA)$ & Optimal $(\AA)$ \\
\hline 1 & $\mathrm{Sn}(1)-\mathrm{C}(44)$ & 2.2339 & 2.1620 \\
2 & $\mathrm{Sn}(1)-\mathrm{C}(47)$ & 2.2064 & 2.1620 \\
3 & $\mathrm{~N}(9)-\mathrm{Sn}(1)$ & 2.1050 & - \\
4 & $\mathrm{~N}(5)-\mathrm{Sn}(1)$ & 2.1010 & - \\
5 & $\mathrm{Sn}(1)-\mathrm{C}(44)$ & 2.2339 & 2.1620 \\
6 & $\mathrm{Sn}(1)-\mathrm{O}(6)$ & 2.0644 & - \\
7 & $\mathrm{O}(6)-\mathrm{C}(7)$ & 1.3666 & 1.3380 \\
8 & $\mathrm{Sn}(1)-\mathrm{O}(2)$ & 2.0581 & - \\
9 & $\mathrm{O}(2)-\mathrm{C}(3)$ & 1.3639 & 1.3380 \\
10 & $\mathrm{Sn}(1)-\mathrm{C}(47)$ & 2.2064 & 2.1620 \\
11 & $\mathrm{~N}(5)-\mathrm{C}(14)$ & 2.1680 & 1.2600 \\
12 & $\mathrm{C}(4)-\mathrm{N}(5)$ & 1.4923 & 1.4700 \\
\hline
\end{tabular}

TABLE 7: Important bond angles of compound $\left[\mathrm{Bu}_{2} \mathrm{Sn}\left(\mathrm{L}^{2}\right)_{2}\right]$.

\begin{tabular}{lcc}
\hline S. number & Atoms & Actual $\left(^{\circ}\right)$ \\
\hline 1 & $\mathrm{C}(47)-\mathrm{Sn}(1)-\mathrm{C}(44)$ & 117.1540 \\
2 & $\mathrm{C}(47)-\mathrm{Sn}(1)-\mathrm{N}(5)$ & 85.7227 \\
3 & $\mathrm{C}(47)-\mathrm{Sn}(1)-\mathrm{N}(9)$ & 124.3910 \\
4 & $\mathrm{C}(47)-\mathrm{Sn}(1)-\mathrm{O}(6)$ & 68.5077 \\
5 & $\mathrm{C}(47)-\mathrm{Sn}(1)-\mathrm{O}(2)$ & 141.0197 \\
6 & $\mathrm{C}(44)-\mathrm{Sn}(1)-\mathrm{N}(5)$ & 80.4837 \\
7 & $\mathrm{C}(44)-\mathrm{Sn}(1)-\mathrm{N}(9)$ & 78.7094 \\
8 & $\mathrm{C}(44)-\mathrm{Sn}(1)-\mathrm{O}(6)$ & 138.6752 \\
9 & $\mathrm{C}(44)-\mathrm{Sn}(1)-\mathrm{O}(2)$ & 88.6745 \\
10 & $\mathrm{~N}(5)-\mathrm{Sn}(1)-\mathrm{N}(9)$ & 148.9524 \\
11 & $\mathrm{~N}(5)-\mathrm{Sn}(1)-\mathrm{O}(6)$ & 139.5356 \\
12 & $\mathrm{~N}(5)-\mathrm{Sn}(1)-\mathrm{O}(2)$ & 69.4566 \\
13 & $\mathrm{~N}(9)-\mathrm{Sn}(1)-\mathrm{O}(6)$ & 67.5865 \\
14 & $\mathrm{~N}(9)-\mathrm{Sn}(1)-\mathrm{O}(2)$ & 87.2268 \\
15 & $\mathrm{O}(6)-\mathrm{Sn}(1)-\mathrm{O}(2)$ & 112.0005 \\
\hline
\end{tabular}

of the distorted octahedral structure. The two Sn-O bond distances are close to being identical values. The calculated $\mathrm{Sn}-\mathrm{O}$ bond distances of 2.0581/2.0644 $\AA$ in $\mathrm{Bu}_{2} \mathrm{Sn}\left(\mathrm{L}^{2}\right)_{2}$ are also close to the already reported $\mathrm{Sn}-\mathrm{O}$ distances in $\left\{\mathrm{CH}_{2} \mathrm{~N}(\mathrm{Me}) \mathrm{CH}(\mathrm{Me}) \mathrm{CH}(\mathrm{Ph}) \mathrm{O}\right\}_{2} \mathrm{Sn}(2.048 / 2.078)$ [49]. The two different $\mathrm{Sn}-\mathrm{N}$ distances of Sn1-N5 and Sn1-N9 in compounds $\mathrm{Bu}_{2} \mathrm{Sn}\left(\mathrm{L}^{2}\right)_{2}$ are 2.1010/2.1050 $\AA$, which are similar to the already reported structures, Salen $\mathrm{H}_{2} \mathrm{Sn}$ 2.0535(9) and $2.0369(8) \AA$ ) [50].

3.8. In Vitro Antibacterial Activity. Antibacterial screening of the synthesized compounds was carried out using four bacterial strains of Gram-positive (B. cereus, Staphylococcus spp.) and Gram-negative (E. coli, Klebsiella spp.) bacteria. The zones of inhibition values in Table 8 represent the mean value of the three readings with standard deviation. Streptomycin was used as a reference compound for antibacterial activities. These bacterial strains are used because they are known as common pathogens of human beings. The antimicrobial 
TABLE 8: Antibacterial activity of ligands and their organotin(IV) complexes.

\begin{tabular}{|c|c|c|c|c|c|c|c|c|}
\hline \multirow{4}{*}{ Schiff bases/complexes } & \multicolumn{8}{|c|}{ Zone of inhibition (mm) } \\
\hline & \multicolumn{4}{|c|}{ Gram-negative } & \multicolumn{4}{|c|}{ Gram-positive } \\
\hline & \multicolumn{2}{|c|}{ E. coli } & \multicolumn{2}{|c|}{ Klebsiella spp. } & \multicolumn{2}{|c|}{ B. cereus } & \multicolumn{2}{|c|}{ Staphylococcus spp. } \\
\hline & $500 \mathrm{ppm}$ & $200 \mathrm{ppm}$ & $500 \mathrm{ppm}$ & $200 \mathrm{ppm}$ & $500 \mathrm{ppm}$ & $200 \mathrm{ppm}$ & $500 \mathrm{ppm}$ & $200 \mathrm{ppm}$ \\
\hline $\mathrm{L}^{2} \mathrm{H}$ & $18 \pm 0.6$ & $15 \pm 0.1$ & $22 \pm 0.6$ & $17 \pm 0.1$ & $14 \pm 0.2$ & $12 \pm 0.9$ & $23 \pm 0.2$ & $20 \pm 0.7$ \\
\hline $\mathrm{Bu}_{2} \mathrm{Sn}\left(\mathrm{L}^{2}\right)_{2}$ & $25 \pm 0.7$ & $22 \pm 0.4$ & $30 \pm 0.3$ & $26 \pm 0.8$ & $20 \pm 0.7$ & $18 \pm 0.4$ & $30 \pm 0.1$ & $25 \pm 0.5$ \\
\hline $\mathrm{L}^{3} \mathrm{H}$ & $12 \pm 0.1$ & $10 \pm 0.3$ & $15 \pm 0.1$ & $13 \pm 0.6$ & $20 \pm 0.1$ & $18 \pm 0.6$ & $21 \pm 0.5$ & $18 \pm 0.6$ \\
\hline $\mathrm{Bu}_{2} \mathrm{Sn}\left(\mathrm{L}^{3}\right)_{2}$ & $16 \pm 0.4$ & $15 \pm 0.6$ & $18 \pm 0.5$ & $16 \pm 0.4$ & $32 \pm 0.1$ & $28 \pm 0.3$ & $30 \pm 0.2$ & $27 \pm 0.2$ \\
\hline $\mathrm{L}^{5} \mathrm{H}$ & $14 \pm 0.3$ & $12 \pm 0.9$ & $15 \pm 0.2$ & $12 \pm 0.1$ & $24 \pm 0.6$ & $20 \pm 0.1$ & $19 \pm 0.1$ & $17 \pm 0.1$ \\
\hline $\mathrm{Bu}_{2} \mathrm{Sn}\left(\mathrm{L}^{5}\right)_{2}$ & $20 \pm 0.5$ & $18 \pm 0.1$ & $20 \pm 0.5$ & $18 \pm 0.5$ & $28 \pm 0.3$ & $23 \pm 0.4$ & $29 \pm 0.4$ & $25 \pm 0.6$ \\
\hline $\mathrm{L}^{6} \mathrm{H}$ & $11 \pm 0.3$ & $13 \pm 0.2$ & $10 \pm 0.1$ & $8 \pm 0.5$ & $20 \pm 0.5$ & $17 \pm 0.8$ & $18 \pm 0.6$ & $15 \pm 0.2$ \\
\hline $\mathrm{Bu}_{2} \mathrm{Sn}\left(\mathrm{L}^{6}\right)_{2}$ & $16 \pm 0.2$ & $15 \pm 0.5$ & $11 \pm 0.8$ & $10 \pm 0.9$ & $24 \pm 0.9$ & $19 \pm 0.5$ & $20 \pm 0.1$ & $18 \pm 0.4$ \\
\hline Streptomycin & $28 \pm 0.1$ & $23 \pm 0.3$ & $26 \pm 0.3$ & $20 \pm 0.5$ & $26 \pm 0.8$ & $22 \pm 0.1$ & $32 \pm 0.1$ & $26 \pm 0.3$ \\
\hline DMSO & 0 & 0 & 0 & 0 & 0 & 0 & 0 & 0 \\
\hline
\end{tabular}

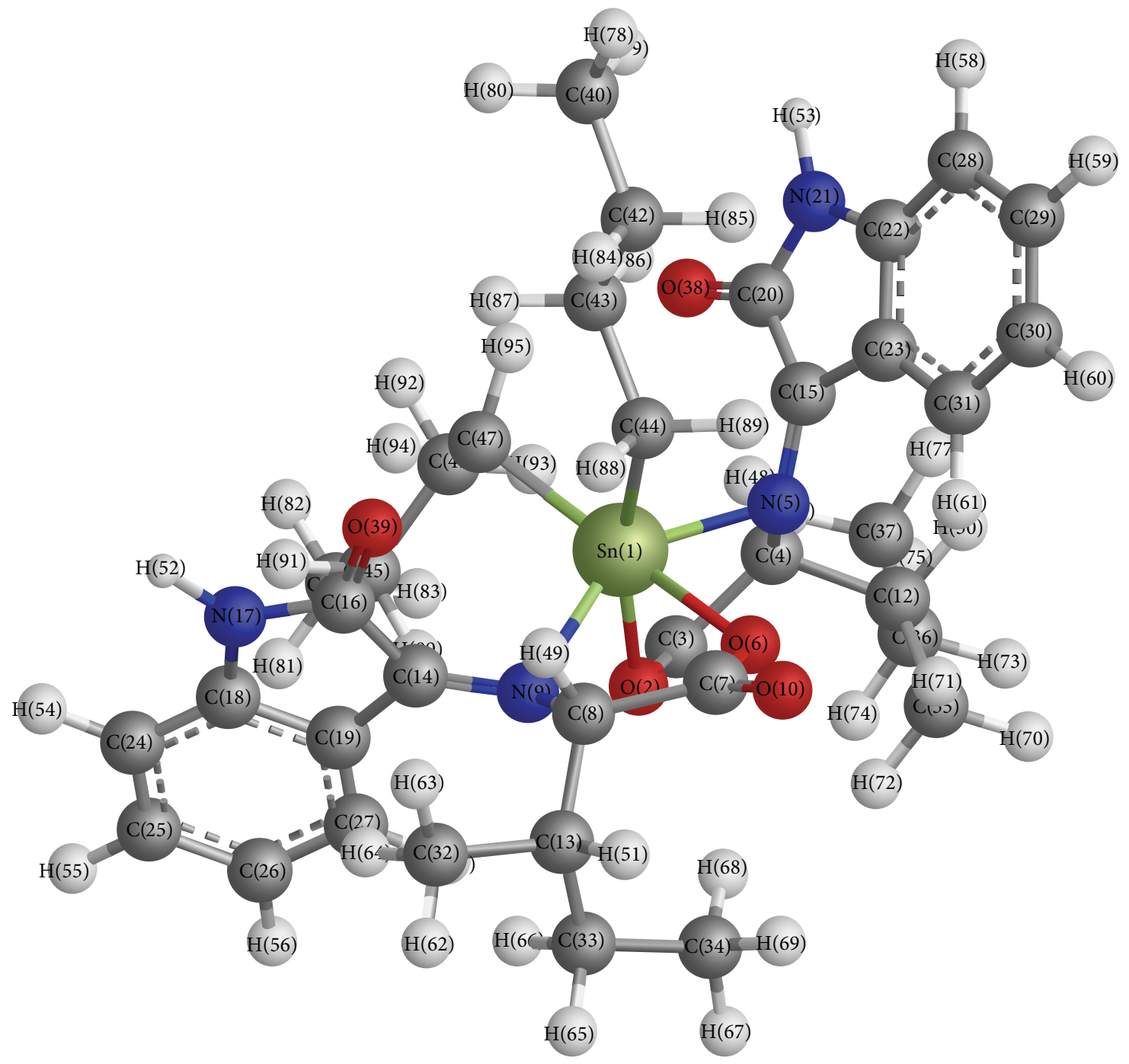

FIgURE 4: 3D molecular structure of $\mathrm{Bu}_{2} \mathrm{Sn}\left(\mathrm{L}^{2}\right)_{2}$. 
studies suggested that the Schiff bases are biologically active and their metal complexes showed significantly enhanced antibacterial activity against microbial strains in comparison to the free ligands, and also crystalline materials are more active than the amorphous materials. Tested compounds showed zone of inhibition ranging from $14.2 \mathrm{~mm}$ to $32.1 \mathrm{~mm}$ against the Gram-positive bacteria and between $10.1 \mathrm{~mm}$ and $25.7 \mathrm{~mm}$ against Gram-negative bacteria. The ligands (HL) show zone of inhibition ranging from $14.2 \mathrm{~mm}$ to $21.5 \mathrm{~mm}$ against Gram-positive bacteria and from $10.1 \mathrm{~mm}$ to $22.6 \mathrm{~mm}$ against Gram-negative bacteria. It has been observed that the metal complexes showed increased zone of inhibition against the bacterial strains compared to ligands. On the basis of zone of inhibition produced against the test bacterium, compound $\mathrm{Bu}_{2} \mathrm{Sn}\left(\mathrm{L}^{3}\right)_{2}$ was found to be the most effective against B. cereus, Staphylococcus spp., E. coli, and Klebsiella spp.with zone of inhibition of $32.1 \mathrm{~mm}, 31.2 \mathrm{~mm}, 16.4 \mathrm{~mm}$, and $18.5 \mathrm{~mm}$, respectively (Table 8 ). This also showed that the antibacterial activity of ligands is greatly enhanced when it is coordinated with metal ions. Although it is difficult to make out an exact structure-activity relationship between the antimicrobial activity and the structure of these complexes, it can possibly be concluded that the chelation as well as the addition of a substrate enhances the activity of the complexes. The increase in the activity of the complexes compared to that of the ligands can be explained on the basis of Overton's concept [51] and Tweedy's chelation theory [52]. Chelation considerably reduces the polarity of the metal ion because of partial sharing of its positive charge with the donor group and possible $\pi$-electron delocalization over the whole chelate ring. Such chelation could enhance the lipophilic character of the metal atom, which subsequently favours its permeation through the lipid layers of the cell membrane. In general, metal complexes are more active than ligands and they may serve as principal cytotoxic species. Thus, exhibiting their broad spectrum nature can be further used in pharmaceutical industry for mankind as an antimicrobial agent after testing its toxicity to human beings.

\section{Conclusion}

A new series of organotin complexes were prepared in good yields. Based on various physiochemical and structural investigations, it was concluded that the ligands act as bidentate (no donor) forming distorted octahedral complexes with $\mathrm{Bu}_{2} \mathrm{Sn}(\mathrm{IV})$ ion. Furthermore, the current study strongly demonstrates that these complexes are more effective antibacterial agents than the parent ligands. Selectivity is observed in the activities of some compounds over particular microorganisms, which is very important for the future pharmaceutical applications in order to avoid the side effects, so we can conclude that the compounds synthesized and tested look very promising.

\section{Conflict of Interests}

The authors declare that there is no conflict of interests regarding the publication of this paper.

\section{Acknowledgments}

The authors are thankful to Professor J. V. Desai, Dean of the Faculty of Engineering \& Technology, Mody University of Science and Technology, Laxmangarh, Sikar, for providing necessary facilities to carry out this research work. They are also thankful to Dr. Tejpal Dewa, Department of Microbiology, University of Delhi, for providing antimicrobial screening facilities.

\section{References}

[1] Z. Moradi-Shoeili, Z. Amini, D. M. Boghaei, and B. Notash, "Synthesis, X-ray structure and ascorbic oxidation properties of ternary $\alpha$-amino acid Schiff base-bipy $\mathrm{Cu}$ (II) complexes as functional models for ascorbic oxidase," Polyhedron, vol. 53, pp. 76-82, 2013.

[2] A. R. Patil, K. J. Donde, S. S. Raut, V. R. Patil, and R. S. Lokhande, "Synthesis, characterization and biological activity of mixed ligand $\mathrm{Co}$ (II) complexes of schiff base 2-amino-4-nitrophenoln-salicylidene with some amino acids," Journal of Chemical and Pharmaceutical Research, vol. 4, no. 2, pp. 1413-1425, 2012.

[3] Z. S. M. Al-Garawi, I. H. R. Tomi, and A. H. R. Al-Daraji, "Synthesis and characterization of new amino acid-schiff bases and studies their effects on the activity of ACP, PAP and NPA enzymes (In Vitro)," E-Journal of Chemistry, vol. 9, no. 2, pp. 962-969, 2012.

[4] F. Ciolan, L. Patron, G. Marinescu, N. Cioatera, and M. Mureseanu, "Synthesis and characterization of $\mathrm{Zn}$ (II) binuclear complexes with three schiff bases derived from some amino acids and 2,2' -(propane-1,3- diyldioxy)dibenzaldehyde," Revista de Chimie, vol. 62, no. 12, pp. 1145-1149, 2011.

[5] P. R. Reddy, A. Shilpa, N. Raju, and P. Raghavaiah, "Synthesis, structure, DNA binding and cleavage properties of ternary amino acid Schiff base-phen/bipy Cu(II) complexes," Journal of Inorganic Biochemistry, vol. 105, no. 12, pp. 1603-1612, 2011.

[6] M. Nath, S. Goyal, S. Goyal, G. Eng, and N. Ogwuru, "Synthesis, spectral and thermal studies of organotin(IV) complexes of $\mathrm{N}$ acetylamino acids," Synthesis and Reactivity in Inorganic and Metal-Organic Chemistry, vol. 28, no. 10, pp. 1619-1641, 1998.

[7] A. S. P. Azzouz and R. T. Ali, "Synthesis of Schiff bases derived from benzaldehyde and salicylaldehyde with some amino acids by a new develop method," National Journal of Chemistry, vol. 37, pp. 158-168, 2010.

[8] M. Shakir, N. Shahid, N. Sami, M. Azam, and A. U. Khan, "Synthesis, spectroscopic characterization and comparative DNA binding studies of Schiff base complexes derived from 1-leucine and glyoxal," Spectrochimica Acta A: Molecular and Biomolecular Spectroscopy, vol. 82, no. 1, pp. 31-36, 2011.

[9] H. L. Singh, J. B. Singh, and H. Sachedva, "Synthesis, spectroscopic and antimicrobial studies of lead (II) complexes of schiff bases derived from amino acids and isatins," Spectroscopy Letters, vol. 46, no. 4, pp. 286-296, 2013.

[10] R. M. Wang, J. J. Mao, J. F. Song, C. X. Huo, and Y. F. He, "Antioxidant activity of bovine serum albumin binding amino acid Schiff-bases metal complexes," Chinese Chemical Letters, vol. 18, no. 11, pp. 1416-1418, 2007.

[11] A. G. Davies, M. Gielen, K. H. Pannell, and E. R. T. Tiekink, Tin Chemistry: Fundamentals, Frontiers and Applications, John Wiley \& Sons, New York, NY, USA, 2008.

[12] H. L. Singh and J. Singh, "Synthesis, characterization and biological activity of dibutyltin(IV) Schiff base complexes derived 
from substituted isatin and amino acids," Natural Science, vol. 4, no. 3, pp. 170-178, 2012.

[13] X. Shang, X. Meng, E. C. B. A. Alegria et al., "Syntheses, molecular structures, electrochemical behavior, theoretical study, and antitumor activities of organotin(IV) complexes containing 1(4-chlorophenyl)-1-cyclopentanecarboxylato ligands," Inorganic Chemistry, vol. 50, no. 17, pp. 8158-8167, 2011.

[14] D. Point, W. C. Davis, S. J. Christopher et al., "Development and application of an ultratrace method for speciation of organotin compounds in cryogenically archived and homogenized biological materials," Analytical and Bioanalytical Chemistry, vol. 387, no. 7, pp. 2343-2355, 2007.

[15] R. Singh, S. Joshi, and A. K. Agrawal, "Synthesis and structural studies of complexes of $\mathrm{N}$-salicylidine amino acids (glycine, $\mathrm{L}$ leucine with salicyldehyde) derived Schiff base with some bivalent transition metal ions," International Journal of ChemTech Research, vol. 2, no. 1, pp. 728-732, 2010.

[16] M. Tariq, N. Muhammad, M. Sirajuddin et al., "Synthesis, spectroscopic characterization, X-ray structures, biological screenings, DNA interaction study and catalytic activity of organotin(IV) 3-(4-flourophenyl)-2-methylacrylic acid derivatives," Journal of Organometallic Chemistry, vol. 723, pp. 79-89, 2013.

[17] J. Zuo, C. Bi, Y. Fan et al., "Cellular and computational studies of proteasome inhibition and apoptosis induction in human cancer cells by amino acid Schiff base-copper complexes," Journal of Inorganic Biochemistry, vol. 118, pp. 83-93, 2013.

[18] A.-J. Guo, X.-S. Xu, Y.-H. Hu, M.-Z. Wang, and X. Tan, "Effects of ternary complexes of copper with salicylaldehyde-amino acid Schiff base coordination compounds on the proliferation of BGC823 cells," Chinese Journal of Cancer, vol. 29, no. 3, pp. 277282, 2010.

[19] N. Korkmaz, A. G. Gökçe, S. T. Astley, M. Aygün, D. Astley, and O. Büyükgüngör, "A highly novel dinickel complex: a hydrogenbonded anti-skew carboxylate bridge and a 2D supramolecular structure," Inorganic Chemistry Communications, vol. 12, no. 12, pp. 1204-1208, 2009.

[20] P. Conti, M. de Amici, S. J. di Ventimiglia et al., "Synthesis and anticonvulsant activity of novel bicyclic acidic amino acids," Journal of Medicinal Chemistry, vol. 46, no. 14, pp. 3102-3108, 2003.

[21] M.-Z. Wang, Z.-X. Meng, B.-L. Liu, G.-L. Cai, C.-L. Zhang, and X.-Y. Wang, "Novel tumor chemotherapeutic agents and tumor radio-imaging agents: potential tumor pharmaceuticals of ternary copper(II) complexes," Inorganic Chemistry Communications, vol. 8, no. 4, pp. 368-371, 2005.

[22] Y. Zhang, X. Wang, and L. Ding, "Interaction between tryptophan-vanillin Schiff base and herring sperm DNA," Journal of the Serbian Chemical Society, vol. 75, no. 9, pp. 11911201, 2010.

[23] M. Wang, Z. Meng, and J. Fu, "Synthesis and biodistribution of six novel ${ }^{99 m} \mathrm{Tc}$ complexes of 2-hydroxybenzaldehyde-amino acid Schiff bases," Applied Radiation and Isotopes, vol. 64, no. 2, pp. 235-240, 2006.

[24] M. S. Ahmad, M. Hussain, M. Hanif, S. Ali, and B. Mirza, "Synthesis, chemical characterization and biological screening for cytotoxicity and antitumor activity of organotin (IV) derivatives of 3,4-methylenedioxy 6-nitrophenylpropenoic acid," Molecules, vol. 12, no. 10, pp. 2348-2363, 2007.

[25] M. Gielen, “Tin-based antitumour drugs," Coordination Chemistry Reviews, vol. 151, pp. 41-51, 1996.

[26] D. de Vos, R. Willem, M. Gielen, K. E. van Wingerden, and K. Nooter, "The development of novel organotin anti-tumor drugs:
Structure and activity," Metal-Based Drugs, vol. 5, no. 4, pp. 179188,1998

[27] D. Schonfelder and U. Thust, "Chemical structure-biological activity relationships: quantitative approaches," in Proceedings of the 3rd Congress of the Hungarian Pharmacological Society, F. Darvas, Ed., Pergamon Press, 1980.

[28] W. Rehman, M. K. Baloch, and A. Badshah, "Synthesis, spectral characterization and bio-analysis of some organotin(IV) complexes," European Journal of Medicinal Chemistry, vol. 43, no. 11, pp. 2380-2385, 2008.

[29] Q. Li, M. F. C. Guedes da Silva, and A. J. L. Pombeiro, "Diorganotin(IV) derivatives of substituted benzohydroxamic acids with high antitumor activity," Chemistry, vol. 10, no. 6, pp. 1456-1462, 2004.

[30] L. Pellerito and L. Nagy, "Organotin(IV) ${ }^{n+}$ complexes formed with biologically active ligands: equilibrium and structural studies, and some biological aspects," Coordination Chemistry Reviews, vol. 224, no. 1-2, pp. 111-150, 2002.

[31] E. M. Hodnett and W. J. Dunn III, "Structure-antitumor activity correlation of some schiff bases," Journal of Medicinal Chemistry, vol. 13, no. 4, pp. 768-770, 1970.

[32] M. Nath, R. Jairath, G. Eng, X. Song, and A. Kumar, "Synthesis, spectral characterization and biological studies of some organotin(IV) complexes of l-proline, trans-hydroxy-l-proline and lglutamine," Spectrochimica Acta A: Molecular and Biomolecular Spectroscopy, vol. 62, no. 4-5, pp. 1179-1187, 2005.

[33] H. L. Singh and J. B. Singh, "Synthesis and characterization of new lead(II) and organotin(IV) complexes of Schiff bases derived from histidine and methionine," International Journal of Inorganic Chemistry, vol. 2012, Article ID 568797, 12 pages, 2012.

[34] H. L. Singh, M. Sharma, and A. K. Varshney, "Studies of coordination compounds of organotin(IV) with Schiff bases of amino acids," Synthesis and Reactivity in Inorganic and MetalOrganic Chemistry, vol. 30, no. 3, pp. 445-456, 2000.

[35] H. L. Singh and J. B. Singh, "Synthesis and characterization of new lead(II) complexes of Schiff bases derived from amino acids," Research on Chemical Intermediates, vol. 39, no. 5, pp. 1997-2009, 2013.

[36] Chem, "3D Ultra molecular modeling and analysis," Cambridge, UK, http://www.cambridgesoft.com/.

[37] N. L. Allinger, Molecular Structure: Understanding Steric and Electronic Effects from Molecular Mechanics, John Wiley \& Sons, 2010.

[38] H. L. Singh, J. B. Singh, and K. P. Sharma, "Synthetic, structural, and antimicrobial studies of organotin(IV) complexes of semicarbazone, thiosemicarbazone derived from 4-hydroxy3- methoxybenzaldehyde," Research on Chemical Intermediates, vol. 38, no. 1, pp. 53-65, 2012.

[39] F. Ahmad, M. Parvez, S. Ali, M. Mazhar, and A. Munir, "Synthesis and spectral studies of tri- and diorganotin(IV) complexes with 5-benzoyl- $\alpha$-methyl-2-thiopheneacetic acid: crystal structure of $\left[\left(\mathrm{CH}_{3}\right)_{3} \mathrm{Sn}\left(\mathrm{C}_{14} \mathrm{H}_{11} \mathrm{O}_{3} \mathrm{~S}\right)\right]$," Synthesis and Reactivity in Inorganic and Metal-Organic Chemistry, vol. 32, no. 4, pp. 665-687, 2002.

[40] M. Nath, C. L. Sharma, and N. Sharma, "Dibutyltin(IV) complexes of schiff bases derived from aminoacids," Synthesis and Reactivity in Inorganic and Metal-Organic Chemistry, vol. 21, pp. 807-824, 1991. 
[41] G. Roge, F. Huber, H. Preut, A. Silvestri, and R. Barbieri, "Triorganotin and triorganolead derivatives of N-acetylaminoacids," Journal of the Chemical Society, Dalton Transactions, no. 4, pp. 595-600, 1983.

[42] M. S. Singh, M. D. Raju, K. Tawade, and A. K. Singh, "Synthesis and spectroscopic study of some organotin(IV) derivatives of benzilmonothiosemicarbazone," Main Group Metal Chemistry, vol. 21, no. 9, pp. 489-493, 1998.

[43] S. G. Teoh, S. H. Ang, E. S. Looi, C. A. Keok, S. B. Teo, and J. P. Declercq, "Synthesis and crystal structure of di-n-butylbis(2amino-5-chlorobenzoato) tin(IV)," Journal of Organometallic Chemistry, vol. 523, no. 1, pp. 75-78, 1996.

[44] B. Sen Saraswat and J. Mason, "Modes of coordination of 1,2aminothiols in organotin(IV) complexes, as demonstrated by ${ }^{119} \mathrm{Sn},{ }^{15} \mathrm{~N}$ and ${ }^{13} \mathrm{C}$ NMR spectroscopy," Polyhedron, vol. 5, no. 9, pp. 1449-1458, 1986.

[45] J. Holeček, M. Nádvorník, K. Handlíř, and A. Lyčka, " ${ }^{13} \mathrm{C}$ and ${ }^{119}$ Sn NMR spectra of Di-n-butyltin(IV) compounds," Journal of Organometallic Chemistry, vol. 315, no. 3, pp. 299-308, 1986.

[46] P. Comba and T. W. Hambley, Molecular Modeling of Inorganic Compounds, Wiley-VCH, Weinheim, Germany, 1995.

[47] A. P. Murthy, "Electrochemical reductive cleavage of carbonhalogen bonds-application of Marcus theory in the analysis of nonlinear activation-driving force relationships," International Archives of Science and Technology, vol. 6, pp. 10-15, 2006.

[48] P. Kumar, P. Mishra, R. P. Singh, and R. P. Singh, "Synthesis, spectroscopic, XRPD and computational study of transition metal-organic frameworks (TMOFs) derived from (6R)-6- $(\alpha-$ phenyl-D-glycylamino) penicillanic acid," Russian Journal of Inorganic Chemistry, vol. 54, pp. 1301-1309, 2009.

[49] T. Zöller, L. Iovkova-Berends, T. Berends, C. Dietz, G. Bradtmöller, and K. Jurkschat, "Intramolecular $\mathrm{N} \rightarrow$ Sn coordination in tin(II) and tin(IV) compounds based on enantiopure ephedrine derivatives," Inorganic Chemistry, vol. 50, no. 17, pp. 8645-8653, 2011.

[50] D. A. Atwood, J. A. Jegier, K. J. Martin, and D. Rutherford, "Tetradentate $-\mathrm{N}_{2} \mathrm{O}_{2}$ ligand complexes of Tin(II). X-ray crystal structure of [N, $\mathrm{N}^{\prime}$-(1,2-ethylene) bis (salicylaldamine)]tin(II), (SaleanH $\mathrm{H}_{2} \mathrm{Sn}$ ), Journal of Organometallic Chemistry, vol. 503, no. 1, pp. C4-C7, 1995.

[51] E. Abele, "Activation of silicon bonds by fluoride ion in the organic synthesis in the new millennium: a review," Main Group Metal Chemistry, vol. 28, no. 2, pp. 45-69, 2005.

[52] B. G. Tweedy, "Possible mechanism for reduction of elemental sulfur by monilinia fructicola," Phytopathology, vol. 55, pp. 910914, 1964. 

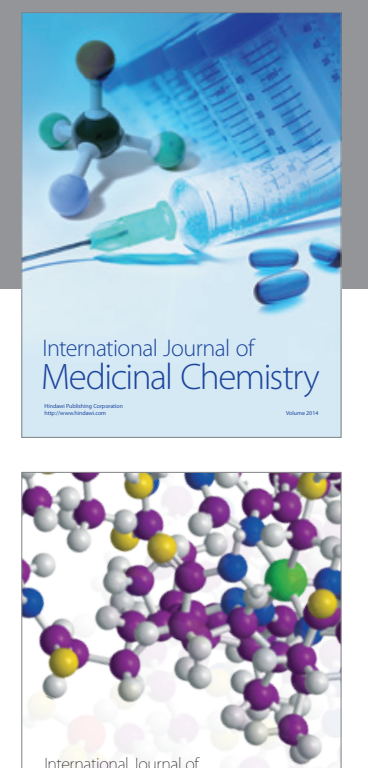

\section{Carbohydrate} Chemistry

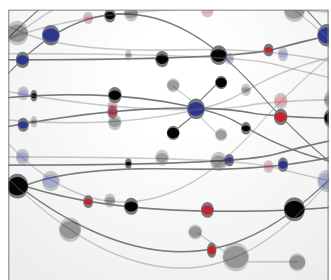

The Scientific World Journal
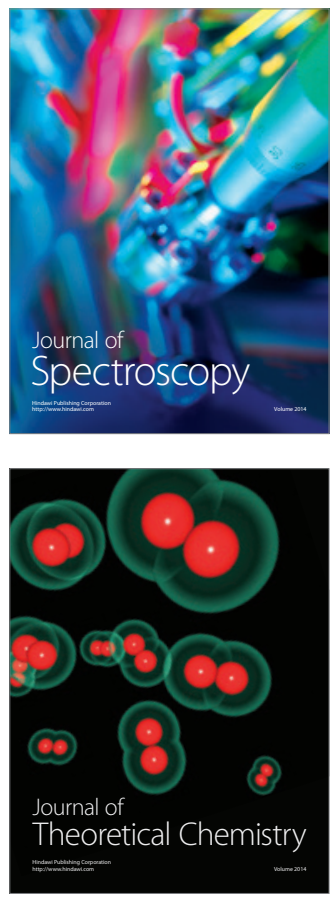
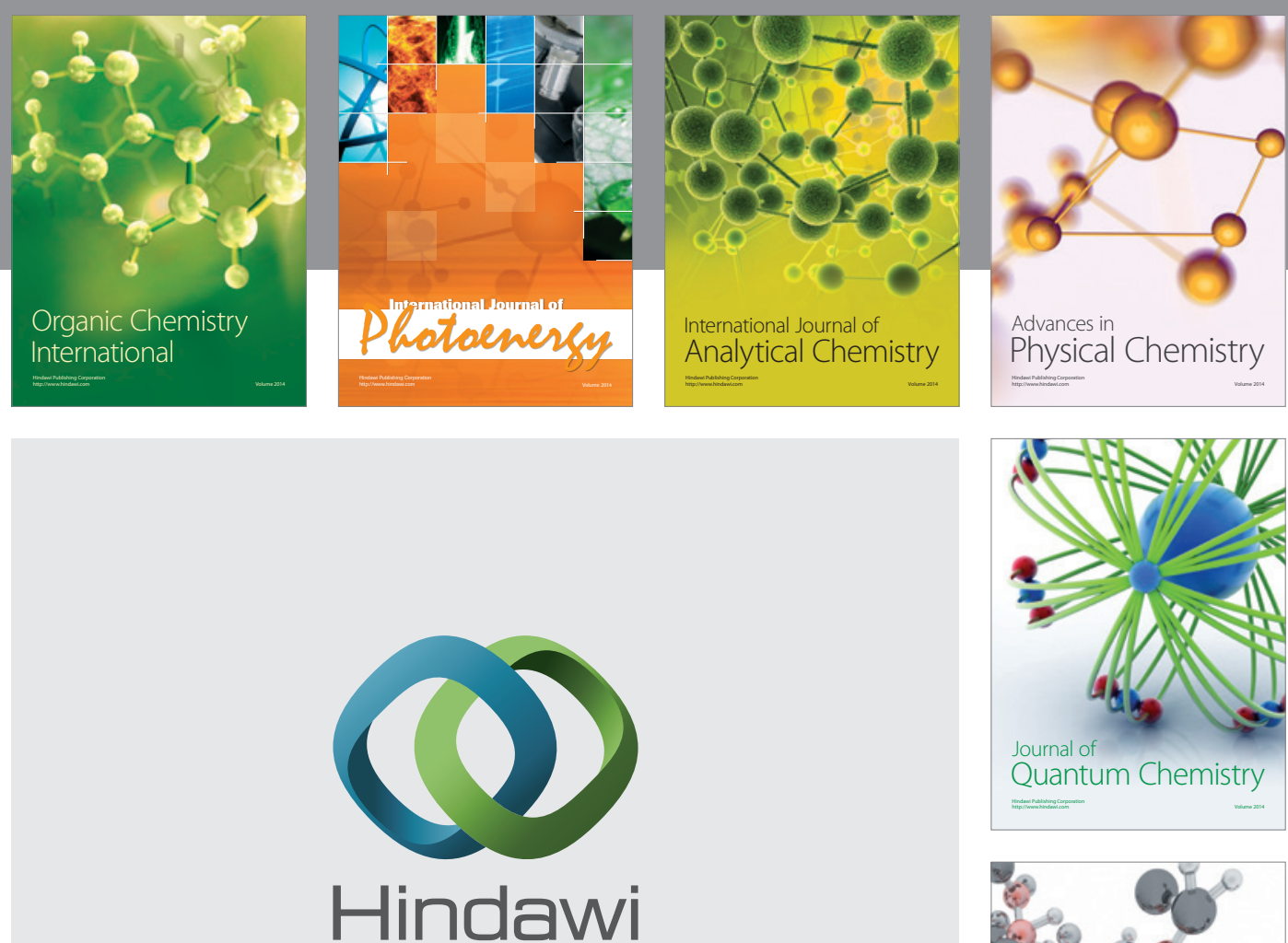

Submit your manuscripts at

http://www.hindawi.com

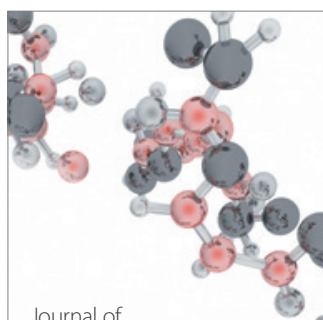

Analytical Methods

in Chemistry

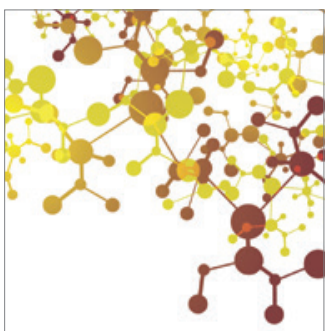

Journal of

Applied Chemistry

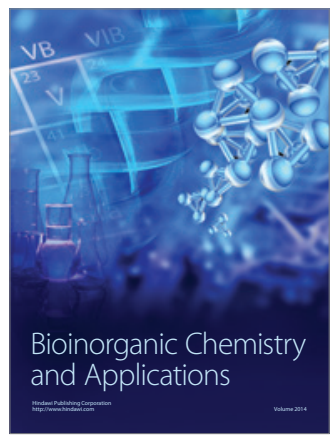

Inorganic Chemistry
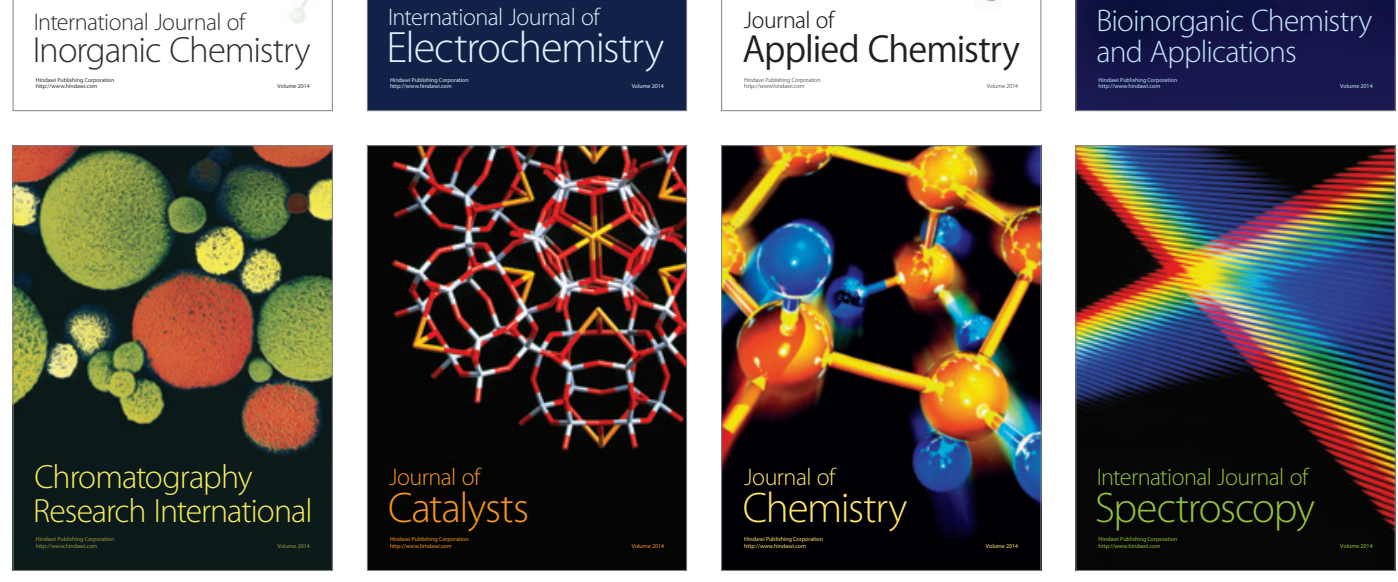